\title{
Az onkológiában alkalmazott immuncheckpointgátló terápiák autoimmun mellékhatásai: patogenezis, klinikum és terápia
}

\author{
Szekanecz Éva dr. ${ }^{1}$. Szekanecz Zoltán dr. ${ }^{2}$ \\ ${ }^{1}$ Debreceni Egyetem, Általános Orvostudományi Kar, Onkológiai Intézet, \\ Onkológiai Nem Önálló Tanszék, Debrecen \\ ${ }^{2}$ Debreceni Egyetem, Általános Orvostudományi Kar, Belgyógyászati Intézet, Reumatológiai Tanszék, Debrecen
}

\begin{abstract}
A daganatterápiát forradalmasította az immuncheckpointgátlók, elsősorban a CTLA4-, PDl- és PDLl-gátlók bevezetése. Alkalmazásuk igazi nyertesei a malignus daganatos betegek: bizonyos tumorlokalizációk esetén ezek a kezelések a legnehezebben uralható rosszindulatú betegségeket is hosszú remisszióban tudják tartani. A kezelések különböző fajtáinak hatásmechanizmusában megnyilvánuló különbségek eltérő mellékhatásprofilban nyilvánulnak meg. A szervspecifikus mellékhatások mellett manifeszt autoimmun betegségek is jelentkezhetnek. A mellékhatás-management terén szemléletváltás szükséges: a szövődmények elhárítását célzó tevékenységeink során nem szabad megfeledkezni arról, hogy az immuncheckpointgátló kezelések mellékhatásai mennyire eltérnek a klasszikus gyógyszeres onkoterápiáknál megszokottól. Ezen tünetek pontos differenciálása esetleges infekciótól vagy a daganatos betegség progressziójától nélkülözhetetlen, de nem egyszerű differenciáldiagnosztikai feladat. Szerencsére számos ajánlás jelent meg az immuncheckpointgátló kezelés mellékhatásainak elhárításával, kezelésével kapcsolatban.
\end{abstract}

Orv Hetil. 2019; 160(23): 887-895.

Kulcsszavak: daganatimmunterápia, kostimuláció, koinhibíció, checkpoint, immuncheckpointgátlás, CTLA4, PD1, PDL1, autoimmun mellékhatások

\section{Autoimmune side effects of immune-checkpoint inhibitor therapies in oncology: pathogenesis, clinic and treatment}

Oncotherapy has been revolutionised by the introduction of immune-checkpoint inhibitors including CTLA4, PD1 and PDLl inhibitors. Patients with malignant diseases may largely benefit from these therapies, which may result in long-term remission even in the most therapy-resistant tumour types. Differences in the mode of action of the various agents may result in varying side-effect profiles. In addition to organ-specific side-effects, overt autoimmune syndromes may also develop. Our current view of oncotherapy has changed as these mostly immune-mediated side-effects highly differ from those observed previously during the administration of traditional anti-tumour compounds. These side-effects should be carefully characterized and differentiated from infections or the progression of the underlying malignancy. Fortunately, several recent recommendations have become available on the management of immune-mediated adverse events due to checkpoint-inhibitor therapy.

Keywords: tumor immunotherapy, costimulation, coinhibition, checkpoint, immune checkpoint inhibition, CTLA4, PDl, PDLl, autoimmune side effects

Szekanecz É, Szekanecz Z. [Autoimmune side effects of immune-checkpoint inhibitor therapies in oncology: pathogenesis, clinic and treatment]. Orv Hetil. 2019; 160(23): 887-895.

(Beérkezett: 2018. december 13.; elfogadva: 2019. január 25.) 


\section{Rövidítések}

APC = (antigen-presenting cell) antigénprezentáló sejt; ASCO $=($ American Society of Clinical Oncology $)$ Amerikai Klinikai Onkológiai Társaság; CIA = (collagen-induced arthritis $)$ kollagénindukált arthritis; CTLA = (cytotoxic T-lymphocyte antigen) citotoxikus T-lymphocyta-antigén; $\mathrm{DC}=($ dendritic cell $)$ dendritikus sejt; ESMO = (European Society for Medical Oncology) Európai Orvosi Onkológiai Társaság; HLA = (human leukocyte antigen) humán leukocytaantigén; IFN $\gamma=$ interferon-gamma; IL = interleukin; $\mathrm{MHC}=$ (major histocompatibility complex) major hisztokompatibilitási komplex; NCCN = (National Comprehensive Cancer Network) Nemzeti Komplex Daganat Hálózat; NOD = (non-obese diabetic $)$ nem elhízott cukorbeteg; $\mathrm{PDI}=($ programmed death 1$)$ programozott halál-1; PDLl = PDl-ligand; PGIA = (proteoglycan-induced arthritis) proteoglikán-indukált arthritis; $\mathrm{RA}=$ rheumatoid arthritis; SITC $=$ (Society for Immunotherapy of Cancer) Daganat Immunterápiás Társaság; SLE $=$ (systemic lupus erythematosus) szisztémás lupus erythematosus; TCR $=(\mathrm{T}$ cell receptor) T-sejt-receptor; $\mathrm{T}_{\mathrm{H}} \mathrm{l}=\mathrm{T}$-helper-1-sejt; $\mathrm{T}_{\mathrm{H}} \mathrm{l}$ - $\mathrm{T}$ helper-17-sejt; $\mathrm{T}_{\mathrm{REG}}=$ regulatorikus $\mathrm{T}$-sejt; $\mathrm{TNF} \alpha=$ (tumor necrosis factor-alpha) tumornekrózisfaktor-alfa; $\mathrm{WHO}=$ (World Health Organization) Egészségügyi Világszervezet

Az immunellenőrző pontok, más néven „immuncheckpointok" (például citotoxikus T-lymphocyta-antigén-4 [CTLA4]-, programmed death 1 [PDI-] receptor- és PDl-ligand [PDLl]-molekulák) az immunrendszer aktivációjának szabályozómolekulái: kulcsszerepet játszanak az immunrendszer múködése egyensúlyának fenntartásában és az autoimmun reakciók kivédésében. Ebből következik, hogy az antigének és az immunsejtek kapcsolódási folyamatainak serkentése, illetve gátlása hatással van az onkoimmunológiai kezelések eredményére [1-3]. Az immuncheckpointgátló terápia térhódítása az onkológiai gyógyszeres kezelések közt fontos mérföldköve a daganatterápiának $[1,2,4-7]$. A jelenleg elérhető és/vagy fejlesztés alatt, bevezetés előtt álló immuncheckpointgátlók közé tartozik a PDl-gátló nivolumab és pembrolizumab, a PDLl-gátló atezolizumab, avelumab és durvalumab, valamint a CTLA4-gátló ipilimumab ( 1 . táblázat) [1, 3, 5, 8-14]. E gyógyszerek indikációi közül kiemelendő a metasztatikus melanoma és a tüdőrákok, de fej-nyaki laphámrákok, máj-, vese-, húgyhólyagtumorok, illetve a Hodgkin-lymphoma kezelésében is egyre szélesebb körben alkalmazzuk e szereket $[1,5-7,9-13$, 15-19]. Ma már nagyon komoly hazai tapasztalatok is vannak ezen kezelésekkel [5-7, 9-11, 16-20].

Az ebbe a csoportba tartozó gyógyszerek mellékhatásprofilja teljesen eltér az eddig megszokott, „klasszikus” kemoterápiák és célzott kezelések okozta toxicitási profiltól. Az immuncheckpointgátló antitestek célpontja nem a tumorsejt maga, hanem a gazdaszervezet immunrendszere. Az aktív immunválasz a daganatos sejtek eliminálására irányul. Ezek alapján, az e közleményben áttekintendő immunpatogenezisü (autoimmun) mellékhatások a védekezőrendszer aktiválódása következtében jönnek létre $[1,2,4,8,10,11,13-16,21-24]$.
1. táblázat | Törzskönyvezett immuncheckpointgátlók (FDA, EMA, 2018)

\begin{tabular}{|c|c|c|}
\hline Molekula & Célpont & Indikáció $^{*}$ \\
\hline Ipilimumab & CTLA4 & $\begin{array}{l}\text { - Melanoma } \\
\text { - Veserák } \\
\text { - Colorectalis cc }\end{array}$ \\
\hline Nivolumab & PDI & $\begin{array}{l}\text { - Melanoma } \\
\text { - Nem kissejtes hörgőrák } \\
\text { - Kissejtes hörgőrák } \\
\text { - Veserák } \\
\text { - Hodgkin-kór } \\
\text { - Hepatocellularis cc } \\
\text { - Fej-nyaki laphámrák } \\
\text { - Urothelialis cc } \\
\text { - Colorectalis cc }\end{array}$ \\
\hline Pembrolizumab & PDl & $\begin{array}{l}\text { - Melanoma } \\
\text { - Nem kissejtes hörgőrák } \\
\text { - Hodgkin-kór } \\
\text { - Fej-nyaki laphámrák } \\
\text { - Urothelialis cc } \\
\text { - Gyomorrák, egyéb szolid tumorok }\end{array}$ \\
\hline Atezolizumab & PDLl & $\begin{array}{l}\text { - Nem kissejtes hörgőrák } \\
\text { - Urothelialis cc }\end{array}$ \\
\hline Avelumab & PDLl & $\begin{array}{l}\text { - Merkel-sejtes cc } \\
\text { - Urothelialis cc }\end{array}$ \\
\hline Durvalumab & PDLl & - Urothelialis cc \\
\hline
\end{tabular}

*Minden daganattípus esetében egyéb feltételek is szerepelnek (például elörehaladott, metasztatikus, genetikai eltérés stb.)

$\mathrm{cc}=$ carcinoma $;$ CTLA $=$ citotoxikus T-lymphocyta-antigén; EMA = Európai Gyógyszerészeti Ügynökség; FDA = az Amerikai Egyesült Államok Élelmiszer-biztonsági és Gyógyszerészeti Hivatala; PD = programozott sejthalál

Ebben az összefoglalóban először röviden áttekintjük az immuncheckpointgátlás alapvető molekuláris mechanizmusait, hogy megérthessük az immunpatogenezisü mellékhatások kialakulását. Preklinikai, főleg állatmodellekben nyert példákkal illusztráljuk a „proof-of-concept” elvét. A klinikumot tekintve pedig áttekintjük az autoimmun mellékhatások epidemiológiáját, klinikumát, valamint a kezelésre, megelőzésre vonatkozó adatokat.

\section{Az autoimmun mellékhatásokat magyarázó sejtes-molekuláris mechanizmusok}

\section{A kostimuláció és koinhibició lényege}

Az immuncheckpointgátlás szempontjából alapvető folyamat a T-sejtek stimulációja („priming”), melynek során az antigénprezentáló sejtek (APC; például dendritikus sejtek, DC) bemutatják az antigént a T-sejtnek. Ezt követően a T-sejt „felkutatja” a daganatsejtet, és optimális esetben elpusztítja azt (effektorfázis). Ez a kezdeti lépés nemcsak az onkológiában, hanem minden antigénfelismerésben kulcsfolyamat $[1,3]$. Ismeretes, hogy az antigénfelismerés során az elsődleges T-sejt-receptor (TCR)/major hisztokompatibilitási komplex (MHC) 
kapcsolódás mellett egy második, ún. kostimulációs szignál is szükséges a folyamathoz. Az APC-n található a B7molekula két formája, a B7-1 és a B7-2. Ha az APC B71-antigénje a T-sejt CD28-molekulájához kötődik, pozitív szignál (kostimuláció) jön létre, és a T-sejt aktiválódik. Amennyiben az APC-n levő B7-2 a T-sejt CTLA4-antigénjével vagy az APC PDLl-molekulája a T-sejt PDl-receptorával kapcsolódik, negatív, gátló szignál (koinhibíció) jön létre, és T-sejt-anergia alakul ki $[1,3]$ (1. ábra). Az effektorfázisban a T-sejt-tumorsejt kölcsönhatás során szintén a TCR-MHC kapcsolat az elsődleges, de ebben az esetben is van gátló szignál. A Tsejt PDl-receptora kapcsolódva a tumorsejt PDLl-ligandjához, koinhibíció jön létre, és a T-sejt nem képes tovább kontrollálni a tumorprogressziót. Újabban kiderült, hogy a PDLl a B7-1-hez is tud kötődni, illetve a PD-ligandnak van egy második (PDL2) formája is $[1,3)$. A CTLA4-, PDl- és PDLl-függő molekulapárokat, valamint az újonnan felfedezett, „Z-generációnak” nevezett egyéb, a továbbiakban részletesen nem ismertetendő kostimulációs (például CD40-CD40L, OX40OX40L, CD137-CD137L) és koinhibíciós (például LAG3-MHC) párokat az 1. ábra tartalmazza.

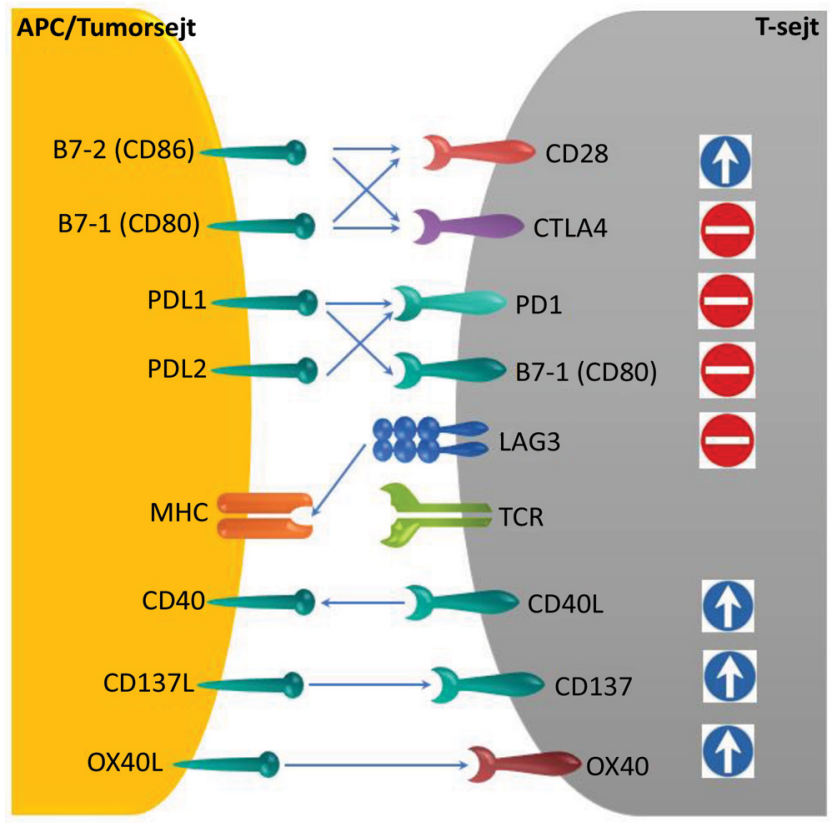

1. ábra A legfontosabb immunellenőrző pontok (checkpointok). A ser-
kentő (kostimulációs), illetve gátló (koinhibíciós) molekula-
párokat a megfelelő „KRESZ-táblákkal” szemléltetjük. Az im-
muncheckpointgátlás szempontjából alapvető folyamat a
T-sejtek stimulációja („priming”), amikor APC-T-sejt kapcsoló-
dás jön létre. Az ábra ugyancsak szemlélteti az ezt követő T-
sejt-tumorsejt kapcsolatokat is. Az antigénfelismeréshez szüksé-
ges TCR-MHC kapcsolódás mellett nélkülözhetetlen egy
második, kostimulációs kapcsolat jelenléte is. E pozitív szigná-
lok mellett léteznek negatív (koinhibíciós) szignált közvetítő
molekulapárok is
APC = antigénprezentáló sejt; MHC = major hisztokompatibi-
litási komplex; TCR = T-sejt-receptor
Az immuncheckpointgátlás alapja tehát a tumorellenes immunitás stimulációja. Az utóbbi mellett ritkán az autoimmun folyamatok is felerősödhetnek, és ezek miatt mellékhatások alakulhatnak ki. A fenti háttér alapján, logikusan, a CTLA4-, PDl/PDLl függő és egyéb rendszerek (1. ábra) serkentése, illetve gátlása, egymással ellentétes folyamatok révén befolyásolja az onkoimmunterápia sikerességét, valamint az autoimmun kórképek kialakulását. Az onkológiai szempontból sikeres immuncheckpointgátlás egyúttal autoimmun jelenségek/ betegségek kialakulását jelentheti (2.ábra) [1,2]. Minderre klinikai példa, hogy amíg a CTLA4-Ig (abatacept) fúziós protein a reumatológiában serkenti a koinhibíciót, ezért autoimmun betegségek (például rheumatoid arthritis) terápiájára alkalmas, az anti-CTLA4-antitest (ipilimumab, tremelimumab) alkalmazása során a T-sejt-tumorsejt közti koinhibíció gátlódik. Az utóbbi folyamat ( „a gátlás gátlása”) azt jelenti, hogy a T-sejt hatékonyan léphet fel a tumorsejt ellen, azonban a koinhibíció gátlása teret enged - többek között a T-sejt-aktiválódáson keresztül - az autoimmun mechanizmusok felerősödésének is. Ugyanez a mechanizmus figyelhető meg az antiPDl - és anti-PDLl-antitestek alkalmazása során (1. és 2. ábra) [1-3]. A 2. ábra szemléletesen, de jelentősen leegyszerúsítve, „libikókák” formájában magyarázza meg a fenti folyamatokat.

A) Egészségesekben a tumorprogresszió és az ez ellen ható immunológiai molekuláris mechanizmusok egyensúlyban vannak, így sem daganat, sem autoimmunitás nem alakul ki.
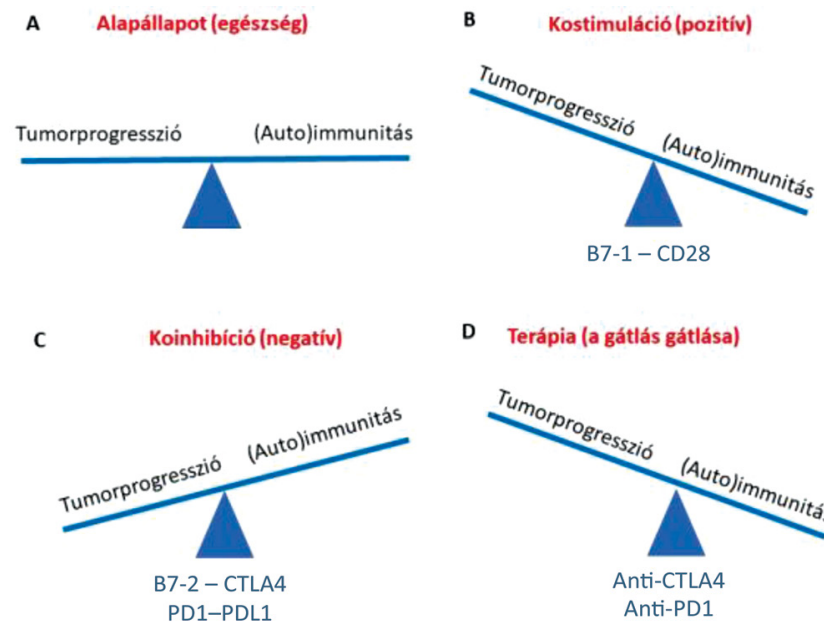

D Terápia (a gátlás gátlása)

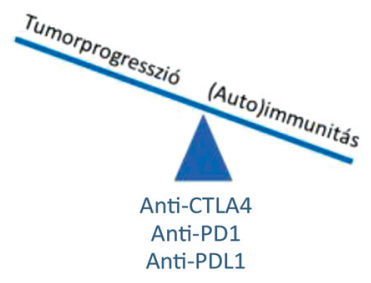

2. ábra

Az immuncheckpointmúködést és - gátlást magyarázó „libikókák”. (A) Alapállapotban a kostimulációs és koinhibíciós folyamatok egyensúlya áll fenn, sem daganatképződés/progressziós, sem autoimmunitás nincs. (B) A pozitív kostimulációs szignál hatására az immunrendszer aktiválódik, ami kedvez a tumorellenes (és auto-)immunitásnak, és a tumorprogresszió ellen hat. (C) A negatív koinhibíciós szignálok hatására az immunválasz gátlása és a tumor progressziója következhet be. (D) A koinhibíció gátlása („a gátlás gátlása”) antitestek vagy szolúbilis koinhibíciós molekulákkal a terápiában felhasználható tumorellenes hatással bír, viszont az autoimmun jelenségek megszaporodhatnak 
B) A B7-1-CD28 molekulapár kostimulációs szignált közvetít, és megnőhet az autoimmun folyamatok rizikója.

C) A B-vel ellentétesen, a B7-2-CTLA4, illetve PDIPDLl közvetítette koinhibíció a tumorprogressziónak kedvez, de az autoimmunitásnak nem.

D) Végül a „a gátlás gátlása”, azaz az immuncheckpointgátlók alkalmazása visszaszorítja a daganatterjedést, viszont autoimmun jelenségeket idézhet elő (2. ábra) $[1,3]$.

\section{Az immuncheckpointgátlás sejtes és molekuláris hatásai röviden}

A CTLA4, PDI és PDLl intracelluláris jelátviteli mechanizmusait és az ezen alapuló sejtélettani változásokat most nem részletezzük. E témában a közelmúltban született összefoglalókra utalunk [1, 2, 25]. Röviden: az immuncheckpointmolekulák gátolják a TCR-MHC kölcsönhatásból eredő T-sejt-aktivációt; gátolják a sejtek túlélését és fokozzák a sejtapoptózist; serkentik az immunszuppresszív hatású regulátor T-sejtek $\left(\mathrm{T}_{\mathrm{REG}}\right)$ müködését; gátolják a sejtek növekedését, fehérjeszintézisét és a glikolízist, valamint serkentik a zsírsav-oxidációt. Mindezek következtében a tumorellenes T-sejtek diszfunkciója következik be, a $\mathrm{T}_{\mathrm{REG}}$ ellenreguláció erôsödik, a sejtek „kimerülnek” és elpusztulnak. Emiatt a T-sejtes immunválasz károsodik, a tumorprogresszió fokozódik. Nyilvánvaló, hogy az immuncheckpointgátlás ellentétesen hatva, a fenti folyamatokat megfordítja, és a T-sejtek túlélnek, aktiválódnak, a tumorprogresszió pedig csökkenhet (2. ábra) [1, 25].

Úgy tûnik, az autoimmunitás kialakulásában valóban alapvető a $\mathrm{T}_{\mathrm{H}} 17 / \mathrm{T}_{\mathrm{REG}}$ egyensúly felborulása. Egészséges körülmények között az IL17-et termelő $T_{\mathrm{H}} 17$-sejtek és a $\mathrm{T}_{\mathrm{REG}}$-sejtek egyensúlya figyelhető meg. Ismeretes, hogy léteznek bipoláris $\mathrm{T}_{\mathrm{H}} 17 / \mathrm{T}_{\mathrm{REG}}$ sejtek, amelyek bizonyos körülmények között akár $\mathrm{T}_{\mathrm{H}} 17$, akár $\mathrm{T}_{\mathrm{REG}}$ irányában is képesek differenciálódni. A PDl és PDLl fokozott expressziója a $\mathrm{T}_{\mathrm{REG}}$, míg a PDl-deficientia vagy -gátlás a $\mathrm{T}_{\mathrm{H}} 17$ irányú differenciálódásnak kedvez. Az előbbi folyamat az autoimmunitás ellen, az utóbbi az autoimmun folyamatok felerősödése irányában hat $[1,26$, 27].

Az egyéb immunológiai tényezők között megemlítendő, hogy a kis mennyiségben jelen levő autoantitestek termelődését az immuncheckpointgátlók fokozhatják. $\mathrm{Az}$ IL17 mellett más proinflammatorikus citokinek (TNF $\alpha$, ILl, IL6) szintje is megemelkedik a kezelt daganatos betegekben. A komplementrendszer szerepére utal, hogy a szöveti CTLA4-antigénhez kötődő antiCTLA4-antitest serkenti a komplementaktivációt [8].

Az egyéb tényezők közül felmerült a genetikai faktorok szerepe. Nem egyértelmű ugyanis, hogy egyes betegeken miért, mások kezelése során pedig miért nem alakulnak ki súlyos adverz események. Egy nagy, 453 melanomás betegen végzett vizsgálat során nem sikerült specifikus genotípussal (MHC/HLA status) összefüggést kimutatni [8]. Felvetődött még mikrobiológiai faktorok (például bizonyos baktériumtörzsek, gastrointestinalis flóra, mikrobiom) szerepe is. Két retrospektív vizsgálat alapján úgy tűnik, hogy egyes diétás manipulációkkal megváltoztatva a bélflórát (például probiotikumok adása), az immunmediált colitis incidenciája csökkenthető, ám ennek bizonyítására még további vizsgálatok szükségesek [8].

\section{Az immuncheckpointgátlás autoimmun mellékhatásaira vonatkozó preklinikai vizsgálatok}

Mint láttuk, az immuncheckpointok által kiváltott intracelluláris szignalizációs folyamatok a T-sejtek pusztulásához vezetnek, tehát az immuncheckpointreceptorok és -ligandok gátlása, melyet a daganatterápiában alkalmazunk, felébresztheti az autoimmunitást $[1,2]$. Erre vonatkozóan néhány preklinikai példát mutatunk be.

Állatmodellekben a PDl-gén deficientiája („knockout" modellek) fokozta a kollagén- (CIA) és proteoglikánindukált arthritis (PGIA), C57BL/6 modellben a szisztémás lupus erythematosus (SLE), BALB/c egerekben az autoimmun cardiomyopathia és NOD egerekben az autoimmun diabetes kialakulását. Ennek hátterében T-sejt- (elsősorban $\mathrm{T}_{\mathrm{H}} \mathrm{l}$ - és $\mathrm{T}_{\mathrm{H}} 17$-) aktivációt és ennek megfelelően fokozott interferon-gamma (IFN $\gamma)$ - és interleukin-17 (IL17)-termelést találtak [26].

Ami a humán ex vivo vizsgálatokat illeti, RA-ban a synovialis membránban és a synovialis folyadékban fokozott PDl - és PDLl-expresszió mutatható ki az egészségesekhez képest. Ezek a koinhibíciós molekulák a $\mathrm{CD}^{+}$ T-sejteken, a $\mathrm{CD}_{19}{ }^{+} \mathrm{B}$-sejteken és a $\mathrm{CDI} 63^{+}$makrofágokon mutathatók ki. A PDl/PDLl koinhibíciós szerepére utal, hogy a PDl-útvonalat serkentő PDL1.Fc fúziós fehérje hatására gátolni lehet a T-sejtek IFN $\gamma$-termelését [28]. SLE-ban a $\mathrm{PDI}^{+}, \mathrm{CD}^{+}{ }^{+} \mathrm{T}$-sejtek aránya megnövekedett a kontrollokhoz képest. E sejtek nagy mennyiségben termelnek a SLE patogenezisében szerepet játszó IFN $\gamma$-t [29]. A látszólagos ellentmondás, mely szerint autoimmun gyulladásos kórképekben fokozott PDl- és PDLl-termelés van, arra utal, hogy a gyulladás miatt feedback formájában beindulnak a koinhibíciós ellenreguláló mechanizmusok. Ugyancsak valószínű, hogy Tsejt-anergia alakul ki a koinhibícióval szemben, így a megnövekedett PDl/PDLl expresszió ellenére az autoimmunitás kialakul [26, 30, 31].

Külön kell szólnunk a szolúbilis PDl (sPDl)- és PDLl (sPDLl)-molekulákról, ezeknek ugyanis szintén patogenetikai szerepük lehet az autoimmun jelenségek kialakulásában [26]. A sPDI a PDCD1-gén alternatív hasítás (splicing), a sPDLl proteolitikus lemetszés (cleavage) révén keletkezik, és az emberi vérben, más testfolyadékokban is kimutatható. A szolúbilis molekulák a megfelelő receptor-ligand kapcsolódás révén (a sPDI a 
2. táblázat |Valódi autoimmun betegségek immuncheckpointgátló kezelés mellett [33]

\begin{tabular}{lll}
\hline Gyógyszer & Autoimmun kórkép & Gyakoriság \\
\hline CTLA4-gátló & Arthralgia és arthritis & $5-16 \%$ \\
& Myalgia és myositis & $2-18 \%$ \\
& Siccaszindróma & $3-4 \%$ \\
& Száraz szem & $3-4 \%$ \\
& Szájszárazság & $7 \%$ \\
\hline PDl-gátló & Arthralgia és arthritis & $5-16 \%$ \\
& Myalgia és myositis & $2-18 \%$ \\
& Siccaszindróma & $3-11 \%$ \\
& Xerostomia & $3-11 \%$ \\
\hline \multirow{2}{*}{ Kombinált kezelés } & Arthralgia és arthritis & $10,5 \%$ \\
& Myalgia és myositis & $1 \%$ \\
& Siccaszindróma & $3-4 \%$ \\
& Xerostomia & $3-4 \%$ \\
\hline
\end{tabular}

CTLA = citotoxikus T-lymphocyta-antigén; PD = programozott sejt halál

sejtfelszíni PDLl-hez, a sPDLl a celluláris PDl-hez kötődik) külső szabályozói a kostimulációs és koinhibíciós folyamatoknak. A „libikókák” vonatkozásában (2. ábra) a sPDI/PDLl az anti-PDI- és anti-PDLl-antitestekhez hasonlóan serkenti a tumorellenes immunitást, emellett kedvez az antivirális immunitásnak és az autoimmunitásnak is $[26,30,31]$. A synovialis T-sejtek sPDLl-termelését a proinflammatorikus citokinek (TNF $\alpha, \operatorname{IFN} \gamma)$ fokozzák [31]. A sPDl és sPDLl nagy mennyiségben mutatható ki a RA-szérumban és synovialis folyadékban, és szintjük korrelál a gyulladásos aktivitással és az ízületi destrukcióval $[30,31]$. Elvileg itt is ellentmondásos, hogy a szolúbilis koinhibíciós molekulák miért nem gátolják a T-sejtek múködését. Valószínú, hogy ez esetben is T-sejt-anergia alakul ki $[26,30,31]$.

Elviekben felmerül a kostimulációs és koinhibíciós útvonalak befolyásolása mint terápiás lehetőség nemcsak az onkológiában, hanem a gyulladásos betegségek kezelésére, megelőzésére is. Ezek a kutatások szintén érdekesek, és fontosak lehetnek az onkológiában alkalmazott im- muncheckpointgátlók autoimmun mellékhatásainak megértéséhez. A RA egyik állatmodelljében a PDl-gén kiütésének („knockout”) hatására az arthritis súlyossága, az ízület destrukciója fokozódott. Ezzel szemben a PDLl.Fc fúziós protein alkalmazásával, amely helyreállítja a PDI/PDLl útvonal múködését, az arthritist gátolni lehetett [28].

\section{Epidemiológia}

A mellékhatások előfordulása sokkal ritkább, mint a hagyományos citotoxikus kezelések mellett. Jellegzetes, hogy viszonylag hamar, a kezelés indítása utáni időszak első heteiben vagy inkább annak elsö 3 hónapjában kezdődnek, azután már csak jóval ritkábban jelennek meg $[10,32]$. Mégis, az immunmediált nemkívánatos események nem jelentenek tartós késői toxicitást, ennek incidenciája nem mutatkozott magasabbnak még hónapokig-évekig tartó immunterápia mellett sem $[2,8,10]$. Ez fontos körülmény, hiszen arra utal, hogy az időben megkezdett onkoimmunterápia a beteg túlélését akár évtizedekben mérve is javíthatja $[8,10]$. A mellékhatások kialakulása szempontjából igen fontos a kezelés időtartama. Egyelöre úgy tûnik, hogy nagyon hosszú ideig is tarthat a terápia. Erre vonatkozóan egyelőre nincsenek pontos ajánlások. Mindenesetre a kezelés időtartamát, ami nyilvánvalóan összefügg a mellékhatások kialakulásának rizikójával, a költségeken túl fóleg a biztonságosság határozza meg $[8,15]$.

Ami a nagyobb vizsgálatokat, metaanalíziseket illeti, a 2. táblázat példaként bemutatja, hogy a PDl-gátló nivolumabbal végzett két (CheckMate 017 és 057) vizsgálatban legalább kétéves követés során milyen mellékhatások fordultak elő, és a gyógyulás mennyi idő után következett be [33]. A 2. táblázat pedig azt mutatja, hogy a CTLA4- vagy PDl-gátló monoterápia, illetve ezek kombinációja milyen gyakorisággal okoz valódi autoimmun jelenségeket [34]. Általánosságban a CTLA4-gátlók mellett súlyosabb toxicitás figyelhető meg, de azt nem sikerült még tisztázni, hogy miért különbözik e rizikó vonatkozásában a CTLA4- és a PDl/PDLl gátlók szervspecificitása $[8,14,15,23]$.

3. táblázat |Ajánlás az autoimmun mellékhatások kezelésére [34]

\begin{tabular}{lll}
\hline Súlyossági fokozat (Grade) & Első vonalbeli kezelés & Másodvonalbeli kezelés \\
\hline Grade 1 (enyhe) & $\begin{array}{l}\text { NSAID } \\
\text { Lokális kortikoszteroid }\end{array}$ & Checkpointgátló terápia? \\
\hline Grade 2 (középsúlyos) & $\begin{array}{l}\text { Kis dózisú kortikoszteroid }(0,5 \mathrm{mg} / \mathrm{kg}) \\
\text { Lokális kortikoszteroid }\end{array}$ & Átmeneti felfüggesztés \\
\hline Grade 3 (súlyos) & Kortikoszteroid $(1-1,5 \mathrm{mg} / \mathrm{kg})$ & $\begin{array}{l}\text { TNF-gátló, metotrexát, szulfaszalazin, Leállítás } \\
\text { klorokin }\end{array}$ \\
\hline Grade 4 (életet veszélyeztető) & Kortikoszteroid $(1-1,5 \mathrm{mg} / \mathrm{kg})$ & $\begin{array}{l}\text { TNF-gátló, metotrexát, szulfaszalazin, Leállítás } \\
\text { klorokin }\end{array}$
\end{tabular}

NSAID = nemszteroid gyulladáscsökkentő gyógyszer; TNF = tumornekrózis-faktor 
Összességében, ezek a mellékhatások egyre több checkpointgátlóval (monoterápiában vagy kombinációban) kezelt betegen kialakulnak. Ennek valószínúleg az lehet a magyarázata, hogy az egyre növekvő (kezelt) betegszám mellett egyre részletesebb, releváns adatot nyerünk $[8,15]$.

\section{Klinikai megjelenés, szervi manifesztációk}

Az immunterápiás szövődmények - az immunrendszer kifejezett aktivitása miatt - a szervezet csaknem valamennyi szervét érinthetik, izoláltan vagy szisztémásan, beleértve a légző-, gastrointestinalis, endokrin szerveket, az idegrendszert, emellett a kültakarót, a szemet és a májat is (3. ábra; 2. táblázat) $[2,8,10,16]$. Az általános tünetek közül fáradtság, kimerültség a vezető panasz PDl/PDLl gátló kezelés mellett (16-37\%), melynek patogenezise nem pontosan ismert $[8,32]$. Emellett, ritkábban, valódi szervspecifikus vagy szisztémás autoimmun betegségek kialakulása is megfigyelhető (2. táblázat) $[2,16,22]$. A fentiekben epidemiológiai szempontból korábban már bemutattuk az immunpatogenezisű jelenségek, autoimmun kórképek felléptének gyakoriságát (2. és 3. táblázat) [33, 34].

\section{Izolált szervi tünetek}

Az alábbiakban gyakorisági sorrendben mutatjuk be az egyes szervek, szervrendszerek területén kialakuló mellékhatásokat (3. ábra; 2. táblázat). Gyakorinak mondható endokrin tünet a hypo- és hyperthyreosis (21-80\%). Az azonnal fel nem ismert endokrin funkciózavar életveszélyessé is válhat $[8,10,15,32,37]$. Egy 38, randomizált vizsgálat (összesen 7551 kezelt beteg) adatait áttekintő metaanalízis szerint a kombinált checkpointgátló terápiát kapók közt a pajzsmirigy múködészavarainak a legmagasabb az incidenciája. A hyperthyreosis gyakoribb volt PDl-, mint PDLl -gátló kezelés során [37]. Ugyancsak relatíve gyakori légzőszervi szövődmény a pneumonitis $(2-9 \%)[8,10,15]$. Az endokrinológussal, pulmonológussal történő konzultáció elengedhetetlen a betegek gondozása során [15, 32, 37]. A leggyakoribb bőrtünetek (59\%) a pruritus és a kiütések. Az előbbi inkább CTLA4-gátló, az utóbbi inkább PDl-gátló mellett jellemző $[8,10,15,32]$. Relatíve gyakran, különösen CTLA4-gátló (27-54\%), ritkábban PDl/PDLl gátló kezelés mellett is $(1-2 \%)$ előfordulhat hasmenés is [8, $10,15,32]$. Az esetek kb. 3\%-ában a mellékhatások viszszatérő jellegűek [32].

Sokkal ritkábban $(<1 \%)$ autoimmun diabetes, hepatitis, colitis, nephritis, lymphocytás myocarditis vagy hypophysitis is kialakulhat $[8,10,15,16,32]$. Az agyalapi mirigy elülső lebenyének gyulladása PDI/PDLl gátló kezelés mellett ma is extrém ritka, de CTLA4-gátlóval kezelt betegek kezelése során 1-16\%-ban is előfordulhat $[15,32]$. Enyhe vagy középsúlyos arthralgia és myalgia, esetleg vasculitisek, myositis is megjelenhet $(2-12 \%)$, fo'-

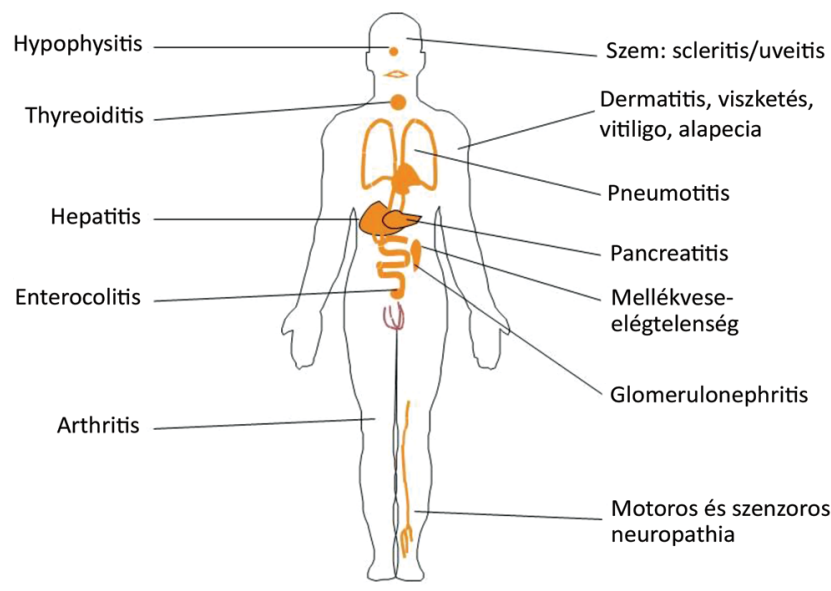

3. ábra

A legfóbb szervspecifikus mellékhatások checkpointgátló kezelés mellett. Szinte bármelyik szervrendszerben autoimmun jelenségek alakulhatnak ki. A szervspecifikus eltérések mellett valódi autoimmun betegségek is megjelenhetnek

leg PDI/PDLl gátló kezelés mellett $[8,32]$. A közelmúltban a WHO-adatbázisban 86 arthritises esetet jelentettek, főleg tüdőrák és melanoma kezelése során. A betegek $80 \%$-a PDl-gátlót kapott [38].

Az egyéb neurológiai szövődmények (például polyneuropathiák, demyelinisatio, arcidegbénulás, myasthenia gravis, myelitisek, encephalitis, asepticus meningitis és Guillain-Barré-szindróma) is viszonylag ritkák (1-3\%). Ilyen esetben nagyon fontos neurológussal felvenni a kapcsolatot annak tisztázására, hogy a tünet nem az alapbetegség progressziójának következménye-e [8, 10, 32]. Ugyancsak nagyon ritkán $(<1 \%)$ primer mellékvesekéreg-elégtelenség, illetve ugyanilyen ritkán szemészeti gyulladásos elváltozások (például uveitis, ulcerativ keratitis, dacryadenitis, retinopathia, neuritis) is felléphetnek $[8,10,15,32]$.

A szervi érintettség mintázatára jellemző, hogy általában nem függ a primer daganat kiindulási helyétől. Mégis megfigyelhető, hogy például tüdőrák miatt kezelt betegeken bizonyíthatóan gyakoribb az immunterápia okozta pneumonitis, mint melanoma miatt kezelteken, bár itt felvetődik annak lehetősége is, hogy a tüdőrákos betegek zöme az immunterápia előtt már sugárterápiát is kapott, mely önmagában is fokozza a pneumonitis rizikóját $[8,37]$. Kombinált CTLA4- és PDI/PDLl gátló kezelés mellett, amely jelenleg még csak melanoma indikációjában alkalmazható, a lehetséges toxicitás kockázata is összeadódik. A mellékhatások hamarabb megjelenhetnek, és hosszabb ideig fennállnak. A kombinációs kezelések 95\%-ában figyeltek meg kezeléssel összefüggő nemkívánatos eseményt, és ezek 55\%-a volt grade 3-4 súlyosságú [32].

\section{Szisztémás autoimmun kórképek}

A fentiek alapján logikus, hogy a CTLA4- és/vagy PDI/ PDLl gátlás során valódi autoimmun kórképek is kialakulhatnak. Ahogy a kezelt betegek száma is rohamosan 
növekszik, ma már több százra, ezerre tehető a publikált autoimmun esetek száma (2. táblázat) [2, 39]. Korábban egyes eseteket, majd kisebb esetszámú kohorszokat közöltek. Így például a Johns Hopkins Egyetemen 2012 és 2016 között ipilimumabbal és nivolumabbal kezelt betegek közül 13 esetben tapasztalták autoimmun betegség, ezen belül rheumatoid arthritis (RA) és Sjögrenszindróma kialakulását [35]. Később, egy francia onkológiai regiszter 447, immunterápiával kezelt betege között két Sjögren-szindrómás, egy cryoglobulinaemiás vasculitises és egy polymyositises eset került felismerése. A négy beteg közül kettő PDl-, kettő pedig PDLl-gátlót kapott [36]. A korábban említett 86 arthritises esetból soknak valódi RA-e volt [38]. Összességében a PDI-, PDL1 - és CTLA4-gátlók mellett arthralgia és arthritis 5-16\%-ban, myalgia és myositis 1-18\%-ban, Sjögrenszindróma 3-11\%-ban fordul elő (2. táblázat) [8, 34, 40].

A Debreceni Egyetem Onkológiai Tanszékén egy immuncheckpointgátlóval kezelt betegben alakult ki autoimmun jelenség. Egy fiatal férfinél 2015 decemberében igazolódott HPV-pozitív pharynxcarcinoma, nyaki nyirokcsomó-metasztázisokkal. A szövettani vizsgálat el nem szarusodó laphámrákot igazolt. Indukciós kezelés, lokoregionális irradiáció után, egyedi engedéllyel 2017 októberétől PDl-gátló nivulumabot kapott. 2018. januárban mindkét kezén kétfázisú Raynaud-szindróma alakult ki. A kapillaroszkópia nem mutatott jellegzetes mintázatot. Szisztémás autoimmun betegségre utaló immunlaboratóriumi eltérés nem volt. A beteg pentoxifillinre jól reagált. Végül nem az autoimmun mellékhatás, hanem tumorrecidíva miatt kellett abbahagyni az immunterápiát [20].

\section{Ismételt autoimmunitás kialakulása}

Mivel az immuncheckpointgátlókkal kezelt betegek száma világszerte rohamosan nő, és a betegek túlélése is javul, egyes esetekben már kettős autoimmunitás kialakulására is számíthatunk. Tudjuk, hogy az autoimmunreumatológiai betegségekben - döntően a szisztémás gyulladás miatt - megnő a szekunder tumorok valószínüsége $[41,42]$. Előfordulhat, hogy ezen autoimmun betegekben daganat alakul ki, amelyet immuncheckpointgátlóval kezelnek [43]. A közelmúltban hat esetet írtak le, amelyben a betegeknek eredetileg valamilyen reumatológiai betegségük volt (RA, vasculitis, Sjögrenszindróma), majd malignitás (öt esetben melanoma, 1-1 esetben hörgőrák) alakult ki. A 6 beteg közül 3 ipilimumabot, 2 pembrolizumabot, 1 nivolumabot kapott. A fenti betegekben 1-20 kezelési ciklus után Grade 2-4 mellékhatások (colitis, pneumonitis, vasculitis fellángolása, hypophysitis) alakultak ki. Mind a hat beteg jól reagált kortikoszteroidokra. A tanulság az volt, hogy a 6 esetból csak 1-nél volt tapasztalható az eredeti autoimmun betegség fellángolása, 5 esetben más, általában szervspecifikus autoimmun jelenség lépett fel [43]. Az ilyen megfigyelések újabb adatokat szolgáltathatnak a daganatképződés és az autoimmunitás kapcsolataira [42, $43]$.

\section{Kezelés, betegkövetés}

Immuncheckpointgátló kezelés előtt, illetve a kezelés alatt rendszeresen dokumentálni és ellenőrizni kell a beteg tüneteit. A szükséges képalkotó vizsgálatok mellett laborvizsgálatok (vese-, mellékvese-, máj- és pajzsmirigyfunkció) is nélkülözhetetlenek lehetnek a szervek funkcionális állapotának monitorozására $[32,44]$. Típusosan a transzaminázemelkedés hívja fel a figyelmet a májtoxicitásra, a bilirubinszint csak alkalmanként emelkedik [44]. Erre azért nagyon fontos figyelni, mert hepatopathia típusosan tünetmentesen is tartósan fennállhat $[37,44]$.

Mivel az immuncheckpointgátló kezelések eredményessége kiemelkedő, elterjedésük kapcsán fontos megtalálni azt a terápiavezetési módszert, amely mellett nem alakulnak ki súlyos, a kezelés folytatását vagy a beteg életét veszélyeztető autoimmun mellékhatások. Mivel a kezelések csak az utóbbi időben terjedtek el az onkológiai gyakorlatban, fontos, hogy az azokat alkalmazó klinikusok megfelelő jártasságot képviseljenek a szövődmények gyors felismerésében és adekvát ellátásában. A lehetséges immunpatogenezisű kezelési mellékhatások bő „választéka" miatt nagyon fontos ezek ellátásában a multidiszciplináris szemlélet. A kollaborációban történő kezelés és betegvezetés nélkülözhetetlen a szövődmények morbiditásának és mortalitásának csökkentése érdekében úgy, hogy az az immunterápia hatékonyságát ne veszélyeztesse $[8,15,45]$. Nagyon fontos az onkológus és az immunológus/reumatológus együttmúködése az ilyen betegek ellátása során $[2,10]$. A mellékhatás-ellátás sikerének titka a megfelelő betegfelvilágosítás. Fontos felhívni a betegek figyelmét arra, hogy elengedhetetlen az új tünetek mihamarabbi jelzése, amikor annak felléptét észlelték. A megfelelő betegedukáció és az idejében történő mellékhatás-jelentés a szövődmények elhárításának egyik sarkalatos pontja. A European Society for Medical Oncology (ESMO) nemrégen közzé is tett egy olyan ajánlást, amely az ilyen mellékhatások ellátásáról szól, de színesen illusztrált betegtájékoztató kiadványok is elérhetők a tünetek megértése, minimalizálása, kezelése és követése érdekében [10, 15, 32].

Ma már konkrét ajánlások is elérhetők például az ESMO [32], az American Society of Clinical Oncology (ASCO) [46], a National Comprehensive Cancer Network (NCCN) [47] és a Society for Immunotherapy of Cancer (SITC) [48] iránymutatásával. A számos ajánlás egyike sem tekinthető „arany standardnak”. A citotoxikus kezelésekhez hasonlóan ez esetben is a tünetek súlyossága (Grade) szerint szükséges azok ellátása, és a közelmúlt óta elérhető mellékhatás-kezelési irányelvek is ez alapján csoportosíthatók. Egy ilyen ajánlott algoritmust mutat be a 3. táblázat [34]. 
A legenyhébb tünetek esetén az immunterápia (néhány hematológiai és neurológiai eltérés kivételével) folytatható, de már Grade 1 fokú, enyhe toxicitás esetén is szorosan kell kontrollálni a beteget (3. táblázat). Közepes erősségű (Grade 2) mellékhatás esetén óvatosság szükséges az immunterápia folytatását illetően, illetve alacsony dózisú kortikoszteroidkezelés indítása mérlegelendő. Kevésbé súlyos tünetek esetén, illetve ha a beteg „időben” megjelent panaszával, szisztémás szteroidterápiára a tünetek hamar oldódnak [10, 34, 44, 48].

Középsúlyos nemkívánatos esemény esetén szisztémás kortikoszteroidkezelés javasolt, minimum 4-6 hétig: Grade 2 súlyosságú mellékhatás esetén általában $0,5-1$ $\mathrm{mg} / \mathrm{kg}$, Grade 3 esetén legalább 1-1,5 mg/ $\mathrm{kg}$ vagy magasabb dózisban (3. táblázat). A kortikoszteroid az ismert módon, a dózist fokozatosan csökkentve hagyható el a tünetek megszünése után. Az immunterápia abban az esetben folytatható, ha a szövődmény megszünik vagy Grade 1 fokozatúra mérséklődik. Ezzel szemben Grade 3 nemkívánatos esemény megszünte után újraindított immunterápia esetén fokozott óvatosság és a beteg igen szoros követése szükséges [10, 34, 44, 48]!

Súlyos, életet veszélyeztető (Grade 4) eltérés esetén az immunterápia megszakítása, a beteg megfelelő intézményben történő hospitalizációja és nagy dózisú szisztémás kortikoszteroid adása szükséges. Ha 2 napos kortikoszteroid- (és szükség esetén antibiotikus) kezelés ellenére sincs javulás, a terápiát más immunszuppresszív szerrel szükséges kiegészíteni: a leggyakrabban antiTNF-biologikum, intravénás immunglobulin (IVIg), mikofenolát-mofetil, illetve ciklofoszfamid adására kényszerülünk [10, 34, 44, 48].

Fontos kiemelni, hogy a szövődményeket rendszeresen ellenőrizni kell, követve a súlyosság változását. Ha az egyéb oki tényező kizárható, és a beteg állapota nem javul a fenti kezelés ellenére sem, az onkoimmunterápiát véglegesen fel kell függeszteni [10, 34, 44, 48]!

Összességében, az immunpatogenezisû mellékhatások pontos ismerete, a felismerés módja, a differenciáldiagnosztika és a kezelés, gondozás elvei elengedhetetlenek az olyan onkológusok számára, akik immuncheckpointgátló terápiát alkalmaznak.

Anyagi támogatás: A munka az Európai Unió Szociális Alap TÁMOP-4.2.4.A/2-11/1-2012-0001. számú „Nemzeti Kiválóság Program” (Sz. Z.), valamint az Európai Unió GINOP-2.3.2-15-2016-00015. és GINOP-2.3.2-15-2016-00050. számú (Sz. Z.) projektjének támogatásával készült.

Szerzői munkamegosztás: A szerzők azonos mértékben járultak hozzá a kézirat elkészítéséhez. A cikk végleges változatát mindketten elolvasták és jóváhagyták.

Érdekeltségek: A szerzőknek nincsenek érdekeltségeik.

\section{Irodalom}

[1] Szekanecz Z, Szekanecz É. Immunological and immunooncological role of PD-1 and PD-Ll. [A PD-1 és PD-Ll immunológiai és immunoonkológiai szerepe.] Immunol Szle. 2017; 9: 23-27. [Hungarian]

[2] Calabrese LH, Calabrese C, Cappelli LC. Rheumatic immunerelated adverse events from cancer immunotherapy. Nat Rev Rheumatol. 2018; 14: 569-579.

[3] Ribas A. Tumor immunotherapy directed at PD-1. N Engl J Med. 2012; 366: 2517-2519.

[4] Postow MA, Callahan MK, Wolchok JD. Immune checkpoint blockade in cancer therapy. J Clin Oncol. 2015; 33: 1974-1982.

[5] Gálffy G. Actual issues in the immunotherapy of lung cancer. [A tüdőtumor immunterápiás kezelésének aktualitásai.] Onkol Hematol (olo.hu). 2018; 8. [Hungarian]

[6] Ostoros G. Advances in immunotherapy. [Az immunterápia térhódítása.] Med Trib. 2018; 16: 14-15. [Hungarian]

[7] Ostoros G. Immunotherapy: a new possibility in the pharmacotherapy of lung cancer. [Újabb lehetôség a tüdőrák gyógyszeres kezelésében: az immunterápia.] Med Thor. 2018; 71: 313-319. [Hungarian]

[8] Postow MA, Sidlow R, Hellmann MD. Immune-related adverse events associated with immune checkpoint blockade. N Engl J Med. 2018; 378: 158-168.

[9] Bellyei S, Bakó P, Orosz É, et al. First report on successful application of nivolumab in Hungary for the treatment of locally recurrent head and neck squamous cell carcinoma. [Immunterápia első hatékony alkalmazása Magyarországon lokálisan kiújult fej-nyaki laphámkarcinómás betegnél.] Magy Onkol. 2018; 62: 175-178. [Hungarian]

[10] Gálffy G. Side-effects of immunotherapies and their treatment. [Az immunterápiák mellékhatásai és kezelésük.] Immunol Szle. 2017; 9: 12-14. [Hungarian]

[11] Ostoros G. Immunotherapy of lung cancer according to recent advances. [A tüdőrák immunterápiája az újabb eredmények tükrében.] Klin Onkol. 2018; 5: 11-15. [Hungarian]

[12] Bogos K. New therapeutic avenues in the treatment of non-small cell lung cancer. [Új terápiás lehetôségek a nem kissejtes tüdőrák kezelésében.] Med Trib. 2018; 16: 18-19. [Hungarian]

[13] Kullmann T. Immunotherapy in the treatment of urothelial cancer. [Immunterápia a húgyhólyagdaganatok kezelésében.] Med Trib. 2018; 16: 12. [Hungarian]

[14] Bertrand A, Kostine M, Barnetche T, et al. Immune related adverse events associated with anti-CTLA-4 antibodies: systematic review and meta-analysis. BMC Med. 2015; 13: 211.

[15] Kazai A. Autoimmune side-effects of checkpoint inhibitors. [A checkpoint inhibitorok autoimmun mellékhatásai.] Med Online 2017. nov 23. [Hungarian]

[16] Gálffy G, Puskás R, Szentkereszty M, et al. Immunotherapy in lung cancer. [Immunterápia tüdőrákban.] Med Thor. 2017; 70: 81-93. [Hungarian]

[17] Liszkay G. Immunotherapy of advanced melanoma. [Az elörehaladott melanoma immunterápiája.] Háziorv Továbbk Szle. 2018; 23: 496-499. [Hungarian]

[18] Liszkay G. Immunotherapy: new way of anticancer pharmacotherapy in skin malignancies. [Immunterápia: a daganatellenes gyógyszeres kezelés új lehetősége a bőrdaganatok területén.] Háziorv Továbbk Szle. 2018; 23: 515-517. [Hungarian]

[19] Géczi L. Immunotherapy: new way of anticancer pharmacotherapy in urology. [Immunterápia: a daganatellenes gyógyszeres kezelés új lehetősége az urológia területén.] Háziorv Továbbk Szle. 2018; 23: 513-514. [Hungarian]

[20] Bodoki L, Csonka T, Szekanecz Z, et al. Autoimmunity induced by checkpoint inhibitor in a patient with head and neck cancer. [Checkpoint inhibitor által indukált autoimmunitás fej-nyak tumoros betegben.] Magyar Reumatol. 2018; 59: 144. [Hungarian] 
[21] van der Vlist M, Kuball J, Radstake TR, et al. Immune checkpoints and rheumatic diseases: what can cancer immunotherapy teach us? Nat Rev Rheumatol. 2016; 12: 593-604.

[22] Calabrese L, Velcheti V. Checkpoint immunotherapy: good for cancer therapy, bad for rheumatic diseases. Ann Rheum Dis. 2017; 76: 1-3.

[23] Boutros C, Tarhini A, Routier E, et al. Safety profiles of antiCTLA-4 and anti-PD-1 antibodies alone and in combination. Nat Rev Clin Oncol. 2016; 13: 473-486.

[24] Cappelli LC, Gutierrez AK, Bingham CO 3rd, et al. Rheumatic and musculoskeletal immune-related adverse events due to immune checkpoint inhibitors: a systematic review of the literature. Arthritis Care Res (Hoboken). 2017; 69: 1751-1763.

[25] Chinai JM, Janakiram M, Chen F, et al. New immunotherapies targeting the PD-1 pathway. Trends Pharmacol Sci. 2015; 36: 587-595.

[26] Dai S, Jia R, Zhang X, et al. The PD-1/PD-Ls pathway and autoimmune diseases. Cell Immunol. 2014; 290: 72-79.

[27] Kobezda T, Ghassemi-Nejad S, Mikecz K, et al. Of mice and men: how animal models advance our understanding of T-cell function in RA. Nat Rev Rheumatol. 2014; 10: 160-170.

[28] Raptopoulou AP, Bertsias G, Makrygiannakis D, et al. The programmed death 1 /programmed death ligand 1 inhibitory pathway is up-regulated in rheumatoid synovium and regulates peripheral $\mathrm{T}$ cell responses in human and murine arthritis. Arthritis Rheum. 2010; 62: 1870-1880.

[29] Dolff S, Quandt D, Feldkamp T, et al. Increased percentages of PD- 1 on $\mathrm{CD}^{+} \mathrm{T}$ cells is associated with higher INF- $\gamma$ production and altered IL-17 production in patients with systemic lupus erythematosus. Scand J Rheumatol. 2014; 43: 307-313.

[30] Greisen SR, Rasmussen TK, Stengaard-Pedersen K, et al. Increased soluble programmed death-1 (sPD-1) is associated with disease activity and radiographic progression in early rheumatoid arthritis. Scand J Rheumatol. 2014; 43: 101-108.

[31] Wan B, Nie H, Liu A, et al. Aberrant regulation of synovial T cell activation by soluble costimulatory molecules in rheumatoid arthritis. J Immunol. 2006; 177: 8844-8850.

[32] Haanen JB, Carbonnel F, Robert C, et al. Management of toxicities from immunotherapy: ESMO Clinical Practice Guidelines for diagnosis, treatment and follow-up. Ann Oncol. 2018; 29(Suppl 4): iv264-iv266.

[33] Horn L, Spigel DR, Vokes EE, et al. Nivolumab versus docetaxel in previously treated patients with advanced non-small-cell lung cancer: Two-year outcomes from two randomized, open-label, phase III trials (CheckMate 017 and CheckMate 057). J Clin Oncol. 2017; 35: 3924-3933.

[34] Tocut M, Brenner R, Zandman-Goddard G. Autoimmune phenomena and disease in cancer patients treated with immune checkpoint inhibitors. Autoimmun Rev. 2018; 17: 610-616.

[35] Cappelli LC, Gutierrez AK, Baer AN, et al. Inflammatory arthritis and sicca syndrome induced by nivolumab and ipilimumab. Ann Rheum Dis. 2017; 76: 43-50.
[36] Le Burel S, Champiat S, Routier E, et al. Onset of connective tissue disease following anti-PDI/PD-Ll cancer immunotherapy. Ann Rheum Dis. 2018; 77: 468-470.

[37] Barroso-Sousa R, Barry WT, Garrido-Castro AC, et al. Incidence of endocrine dysfunction following the use of different immune checkpoint inhibitor regimens: a systematic review and metaanalysis. JAMA Oncol. 2018; 4: 173-182.

[38] Arnaud L, Lebrun-Vignes B, Salem JE. Checkpoint inhibitorassociated immune arthritis. Ann Rheum Dis. 2018 May 3. doi: 10.1136/annrheumdis-2018-213470. [Epub ahead of print]

[39] Calabrese C, Kirchner E, Kontzias K, et al. Rheumatic immunerelated adverse events of checkpoint therapy for cancer: case series of a new nosological entity. RMD Open 2017; 3: e000412.

[40] Hunter G, Voll C, Robinson CA. Autoimmune inflammatory myopathy after treatment with ipilimumab. Can J Neurol Sci. 2009; 36: 518-520.

[41] Szekanecz É, Szűcs G, Kiss E, et al. Secondary malignancies in rheumatoid arthritis. [Szekunder malignus tumorok előfordulása rheumatoid arthritisben.] Lege Artis Med. 2008; 18: 886-892. [Hungarian]

[42] Szekanecz E, András C, Sándor Z, et al. Malignancies and soluble tumor antigens in rheumatic diseases. Autoimmun Rev. 2006; 6: 42-47.

[43] Richter MD, Pinkston O, Kottschade LA, et al. Brief report: cancer immunotherapy in patients with preexisting rheumatic disease: the Mayo Clinic experience. Arthritis Rheumatol. 2018; 70: 356-360.

[44] Friedman CF, Proverbs-Singh TA, Postow MA. Treatment of the immune-related adverse effects of immune checkpoint inhibitors: a review. JAMA Oncol. 2016; 2: 1346-1353.

[45] Postow MA. Managing immune checkpoint-blocking antibody side effects. Am Soc Clin Oncol Educ Book 2015; pp. 76-83.

[46] Brahmer JR, Lacchetti C, Schneider BJ, et al. Management of immune-related adverse events in patients treated with immune checkpoint inhibitor therapy: American Society of Clinical Oncology Clinical Practice Guideline. J Clin Oncol. 2018; 36: 1714-1768.

[47] Thompson JA. New NCCN Guidelines: recognition and management of immunotherapy-related toxicity. J Natl Compr Canc Netw. 2018; 16: 594-596.

[48] Puzanov I, Diab A, Abdallah K, et al. Managing toxicities associated with immune checkpoint inhibitors: consensus recommendations from the Society for Immunotherapy of Cancer (SITC) Toxicity Management Working Group. J Immunother Cancer 2017; 5: 95 .

(Szekanecz Éva dr., Debrecen, Nagyerdei krt. 98., 4032 e-mail: szevadr17@gmail.com)

A cikk a Creative Commons Attribution 4.0 International License (https://creativecommons.org/licenses/by/4.0/) feltételei szerint publikált Open Access közlemény, melynek szellemében a cikk bármilyen médiumban szabadon felhasználható, megosztható és újraközölhető, feltéve, hogy az eredeti szerző és a közlés helye, illetve a CC License linkje és az esetlegesen végrehajtott módositások feltüntetésre kerülnek. (SID_1) 